\title{
A Report on Literature Search and Archaeological Survey in the Vicinity of Point Comfort, Calhoun County, Texas
}

Herbert Uecker

Thomas C. Kelly

Follow this and additional works at: https://scholarworks.sfasu.edu/ita

Part of the American Material Culture Commons, Archaeological Anthropology Commons, Environmental Studies Commons, Other American Studies Commons, Other Arts and Humanities Commons, Other History of Art, Architecture, and Archaeology Commons, and the United States History Commons

Tell us how this article helped you.

This Article is brought to you for free and open access by the Center for Regional Heritage Research at SFA ScholarWorks. It has been accepted for inclusion in Index of Texas Archaeology: Open Access Gray Literature from the Lone Star State by an authorized editor of SFA ScholarWorks. For more information, please contact cdsscholarworks@sfasu.edu. 


\section{A Report on Literature Search and Archaeological Survey in the Vicinity of Point Comfort, Calhoun County, Texas}

\section{Creative Commons License}

\section{(c) (1) \&}

This work is licensed under a Creative Commons Attribution-NonCommercial 4.0 International License 


\section{A REPORT ON LITERATURE SEARCH AND ARCHAEOLOGICAL SURVEY IN THE VICINITY OF POINT COMFORT, CALHOUN COUNTY, TEXAS}

HERBERT UECKER AND THOMAS C, KELLY 


\section{A REPORT ON LITERATURE SEARCH AND ARCHAEOLOGICAL SURVEY IN THE VICINITY OF POINT COMFORT, CALHOUN COUNTY, TEXAS}

Herbert Uecker and Thomas C. Kelly

Center for Archaeological Research The University of Texas at San Antonio Archaeological Survey Report, No. 82 
Page

Introduction. . . . . . . . . . . . . . . . . . 1

The Survey Area . . . . . . . . . . . . . . . . . . 1

Results of the Survey..................... 3

Archaeological Background ..................... 3

Coastal Zone Archaeology. ................ 5

Previous Archaeological Work in Calhoun County. . . . . . . . 7

Historical Data ......................... 9

References Cited. ........................... 10

LIST OF FIGURES

Figure

Page

1. Location of Area Surveyed for the Point Comfort Project . . . . . 2 
During May 1979, archaeologists from the Center for Archaeological Research, The University of Texas at San Antonio, conducted literature research and an archaeological field survey of an area to be developed by the Formosa Plastic Company near Point Comfort, CaThoun County, Texas.

The field and literature survey was done under contract between the Center for Archaeological Research (UTSA) and the Pace Company of Houston, Texas. In this report, the results of the field survey are presented by Thomas C. Kelly, Research Associate of the Center; the literature review was prepared by Herbert Uecker, Technical Staff Assistant. A11 project work was done under the supervision of Dr. Thomas R. Hester, Director of the Center, and Mr. Jack D. Eaton, Assistant Director.

\section{THE SURVEY AREA}

The area surveyed contains approximately 250 acres of land situated on the east side of Point Comfort (Fig. 1). The area is bounded on the west by Highway 1593, on the south by State Highway 35, and on the east by Huisache Creek (Cox Lake). Most of the survey area is grassland used for cattle grazing; however, on the eastern end about 50 acres are under cultivation for feed grain. Local informants relate that the pasture land in the survey area had been farmed on and off since the late 1800s, producing corn, cotton and various grains.

In the eastern sector of the survey land, and located on the-north side of Highway 35 , is the G. S. Traylor Memorial Roadside Park. It was named after Mr. Traylor, an early settler of the area who once owned a large tract of land between Point Comfort and Palacios to the east. His descendants are still living in the area. 
Huisache creek at the eastern-boundary of the survey is a narrow, shallow stream. It is considered part of Cox Lake, which was formed by an impoundment dam located 1.8 miles downstream and installed by the Alcoa Company. Beyond the dam are the tidal flats forming the upper part of Huisache Cove.

In aboriginal times, the tidal flats, which once extended adjacent to the survey area, were probably utilized by local hunting and gathering Indian populations (see literature review). However, almost no evidence of this was found during the survey.

\section{RESULTS OF THE SURVEY}

The project area was surveyed by walking parallel transects, spaced roughly 50 meters apart, in the long east-west axis. The most probable area for prehistoric sites was felt to be along Cox Lake. Therefore, the eastern part of the survey area was examined as well as possible, but the dense grain crop there prevented a thorough examination of the ground surface. About 500 feet of lake shore was carefully examined; the only cultural material found on the shore was a single chert flake.

As a result of the survey, we can report that no significant cultural resources were found that would be affected by planned developments.

\section{ARCHAEOLOGICAL BACKGROUND}

Three distinct major periods of prehistoric cultural development and. cultural change have been distinguished by Texas archaeologists (cf. Fritz 1972:27-23).

1. The Paleo-Indian or Paleo-American period (ca. 9,200 to 6,000 B.C.) is characterized by cultures based substantially on the hunting of large mammals; namely, extinct forms of bison, mammoth, and possibly mastodon, which occupied the Great 
Plains of North America and adjacent fringe areas near the end

of the Pleistocene geologic epoch. Essentially these were small bands of native Americans engaged in a nomadic hunting lifeway, following seasonally migrating game. The climate in most of Texas was comparatively cool and humid, and the landscape was a forest "parkland," a moderate to dense arboreal habitat and savannah grassland with lush vegetation suitable for the sustenance of large herbivorous animals (Hester 1976).

The elevation of sea level along the Texas coast is estimated to have been some 400 feet lower than at present. A broad seaward expanse of land, which is now under seawater, was exposed, and probably extended to the present margin of the Continental Shelf. Numerous rivers and streams emptied into the Gulf of Mexico along the Texas coast and formed broad valleys in the headlands. This once-exposed stretch of land was slowly submerged after Pleistocene times by the melting of glaciers. Thus, coastal archaeological sites dating from the Paleo-Indian period are, with few exceptions, now inaccessible, if not totally destroyed, by the inundation and subsequent erosional disturbances.

2. The Archaic period (ca. 6,000 B.C. to A.D. 1,000) in Texas is generally characterized by a climatic shift to generaity drier conditions, with brief humid intervals which seem to have become more lengthy and numerous in the latter half of the period. The landscape appeared as alternately sparce and lush savannah grasslands, with isolated stands of trees on the uplands, and heavier arboreal growth in the riparian zones. 
This "drying out" of the land after the Pleistocene corresponds

to what were apparently broad changes in the lifeways and culture of native peoples. A substantial degree of diversification in their subsistence patterns appears to have occurred: a shift away from the hunting of Pleistocene mammals (which had become extinct) as food resources, and an emphasis on hunting or capturing smaller game and on plant food gathering, processing, and perhaps even cultivation.

3. In the Late Prehistoric or Neo-American period (ca. A.D. 1,000 to 1,500 ) several pronounced cultural changes are evident. In some parts of Texas, there was the introduction of domestic plant foods; this did not occur on the central coast. The bow and arrow and ceramics were introduced and widely disseminated.

\section{Coastal Zone Archaeology}

Archaeological remains in the Texas coastal zone consist of rare beachfront and inland Paleo-Indian sites, and numerous but usually eroded and disturbed beachfront or estuarine sites dating back to the Middle Archaic period (ca. 3,000 B.C.), some with occupations continuing through the Late Prehistoric into post-European contact (Corbin 1976).

A marine subsistence adaptation, based on the hunting and capturing of moderate sized to small game such as bison, deer, peccary, raccoon, opossum, rabbit, water fowl, rodents, turtles, snakes, and the 1 ike; fishing; and the large-scale gathering and consumption of shellfish (oysters, clams, mussels and conch) was characteristic of these coastal habitations. This adaptation developed in the coastal zone, and was apparently utilized in a uniform fashion for long spans of time. A general continuity of cultural activities from the 
Archaif to ean? H Historic times is wei represented in artifact as semblages

from coastal sites (Corbin 1976).

Campbel1 (1960). has discussed the various types of sites found in the

central section of the Texas coast, the area which includes Calhoun County:

In the central section of the Texas coast the best known type of site is the shell midden, a compact accumulation of marine shells and soil that also includes animal bones, artifacts, and other occupational refuse. In most middens oyster shell predominates, but clam, conch, and other kinds of shell are usually included. These shell middens are circular or oval in outline and vary widely in thickness and size of area covered. They range from a small area of thinly scattered refuse to large accumulations five or six feet thick and covering an area having a maximum diameter of 2,000 feet. The larger middens, which are not numerous, seem to indicate favored areas where groups camped longer and more frequently. The shell middens are usually located on the crests or slopes of knolls, old beach ridges, and other low elevations near the shores of bays or on the higher parts of small islands near the bay shores. In areas that have been carefully surveyed it has been found that nearly every location suitable for human habitation exhibits shell midden materials. This does not necessarily signify a dense population at any one time; more likely it means full exploitation of the shore line environment over a considerable period of time.

Other types of sites are known to exist on the coast, but they have not received much attention. These include campsites buried in valley alluvium, campsites located on or in natural levees of abandoned stream channels, and sand dune campsites on the offshore barrier islands and peninsulas.

Although numerous burials have been reported from the Texas coast, very few have been described. In shell middens and in clay dune sites both flexed and extended burials have been found. As most of these yield no burial furniture, cultural assignment of skeletal material is especially difficult. In the vicinity of Corpus Christi burial areas have been found that yielded scores of skeletons, but these have not yet been linked with specific cultural units.

These buriais occur both within shell midden sites and in isolated burial

sites. Wingate and Hester (1972) have reported 10 Late Prehistoric burials

from near Green Lake in CaThoun County.

During Historic times, the central part of the Texas Gulf Coast was occupied

largely by the Karankawa Indians. Newcomb (1960) has described the Karankawa

life ways and appearance: 
The typical Karankawa band (such as the Capoque and Han whom Cabeza do Vaca was acquainted with in the Galveston area) led a wandering existence, determined by the availability of various wild cane weirs and eating the roots of certain underwater plants. In February the roots become useless as food and the bands were forced to move. Until April they subsisted mainly on oysters that were found in abundance along the mainland shores. As summer approached the coastal dwellers moved inland to harvest the fruits of various cacti, principally tunas of the prickly pear. Oddly, the Karankawa never seem to have become the seafaring people they could have been. Their canoes were adequate for short journeys in bays in sight of land, but they lacked sails, fishhooks and especially a viewpoint which would have allowed them to reap the rich harvest of the teeming Gulf waters.

Previous Archaeological Work in Calhoun County

Although there are apparently no published manuscripts or site survey records on previous archaeological work in the immediate vicinity of the present survey, i.e., the Point Comfort-Huisache Creek area, a significant number of archaeological sites have been discovered and recorded in other portions of Calhoun County.

There are presently 62 Calhoun County sites on file with the Texas Archeological Research Laboratory (TARL) in Austin (Carolyn Spock, personal communication). Due to time limitations, the author was not able to directly examine information on file at TARL prior to preparation of this report; thus data on only approximately 55 of the 62 sites are presented here. Investigations pertaining to these sites were performed by both amateur and professional archaeologists, from ca. 1932 to the present survey in June 1979.

The earliest known archaeological work in the county is that of $A$. M. Woolsey, who in. July 1932 recorded eight of what were apparently prehistoric sites at or near Indianola. Presumably no excavations were performed by Woolsey. During the middle and late 1960s, a very knowledgeable local avocational archaeologist, Cecil Calhoun, recorded two additional prehistoric sites near Green Lake. Calhoun has reported and mapped many archaeological sites in Calhoun 
County for the Texas Highway Department (Fritz 1975). The most notable of

these is $41 \mathrm{CL} \mathrm{1,} \mathrm{described} \mathrm{by} \mathrm{Wingate} \mathrm{and} \mathrm{Hester} \mathrm{(1972):}$

...an 18 inch thick midden accumulation of Rangia sp., oyster, and other marine shells, and land snails. Calhoun also noted the presence of baked clay lumps, asphaltum, sherds of Rockport ware, bone awls, milling stone fragments, flake scrapers, seven Scallorn arrow points, and a stemmed dart point. Calhoun excavated one burial at the site and noted fragmentary remains of two others. Calhoun has observed that archaeological materials are scattered all along the northern, western and eastern margins of Green Lake.

R. J. Wingate excavated a burial site at Green Lake in 1960. This site, containing 10 Late Prehistoric burials, has been mapped and recorded; the investigator's results were reported by Wingate and Hester (1972).

In 1972, and again in 1975 Gayle Fritz (1975) visited the Matagorda-Cox bay area and mapped and recorded an additional 30 Calhoun County Archaic-Late Prehistoric sites, mostly shell middens, located along the beach fronts.

In 1973, Comstock, Grombacher and Dibble (1973) performed a study of the effects of shell dredging on the archaeological and historical resources of San Antonio Bay for the Texas. Antiquities Committee, mapping and recording several prehistoric and historic sites near the bay. In October 1974, Feris Bass of the Center for Archaeological Research (UTSA) performed a survey of archaeological resources on 484 acres of Chocolate Creek, Little Chocolate Creek and Lynns Bayou for the United States Department of Agriculture, Soil Conservation Service. Due to intensive artificial disturbances such as ditching, channeling, and similar drainage modification in the area, no recognizabie sites were observed or recorded (Bass 1974).

In 1978, Frank Hole, an archaeologist working for Engineering Science, Inc. of Austin, performed a survey of cultural resources in the Green Lake area. Hole (1978) has reported five prehistoric sites to the Texas Archeological Research Laboratory. 
Details of the history of Calhoun County are confined mostly to numerous articles on the town of Indianola, a shipping port located on the far western shore of Matagorda Bay (cf. Boozer 1942; Fritz 1975; Webb 1952).

Rene Robert Cavelier de la Salle landed in Calhoun County in 1685; a monument was erected by the Texas Centennial Commission in 1936 to mark the locality (Webb 1952).

A search of the files of the National Register of Historic Places revealed that only one site in Calhoun County, the Cava17o Pass Light Station, has been declared eligible for National Register nomination (Lissa Anderson, personal communication). The Light Station, built in 1852, was destroyed during the Civil War and again in the hurricane of 1886 . It is now federally owned and still in operation. 
Bass, F. A., Jr.

1974 Assessment of Archaeological Resources in Portions of the Chocolate Creek, Little Chocolate Creek and Lynns Bayou Watershed. Center for Archaeological Research, The University of Texas at San Antonio, Archaeological Survey Report 2.

Boozer, J. B.

1942 The History of Indianola, Texas. M.A. Thesis. The University of Texas, Austin.

Campbe11, T. N.

1960 Archeology of the Central and Southern Sections of the Texas Coast. Bulletin of the Texas Archeological Society 29:145-171.

Comstock, D. B.., K. A. Grombacher and D. S. Dibble

1973 A Study of the Effects on Shell Dredging of the Archeological and and Historical Resources of San Antonio Bay, Texas. Texas Archeological Survey Research Report 33.

Corbin, J. E.

1976 The Archaic of the Texas Coast. In, The Texas Archaic: A Symposium, edited by Thomas R. Hester. Center for Archaeological Research, The University of Texas at San Antonio, Special Report 2.

Fritz, G.

1972 Pilot Archeological Field Survey, Cox Bay, Calhoun County, Texas. Matagorda Bay-Estuarine Resource Management Study, Texas General Land Office, Austin.

1975 Matagorda Bay Area, Texas: A Survey of the Archeological and Historical Resources. Published jointly by the Planning Division, Texas General Land Office and Texas Archeological Survey, The university of Texas at Austin. Research Report 45.

Hester, T. R.

1976 Hunters and Gatherers of the Rio Grande Plain and the Lower Coast of Texas. Center for Archaeological Research, The University of Texas at San Antonio. 
Hole, $F$.

1978 Cultural Resources Assessment of the Vistron Petrochemical Complex, Calhoun County, Texas. Unpublished manuscript prepared for Engi-
neering Science, Inc., Austin.

Newcomb, W. W., Jr.

1960 Indian Tribes of Texas. Bulletin of the Texas Archeological Webb, W. P., editor

1952 The Handbook of Texas. Texas State Historical Association,
Austin. Wingate, R. J. and T. R. Hester

1972 Ten Burials from Green Lake, Texas. Florida Anthropologist 25:
119-126. 